
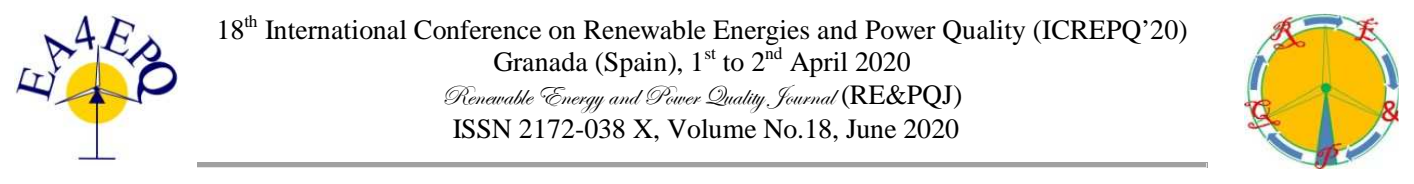

\title{
Experimental Analysis of Fin Pitch Distance Variation of Adsorber for Adsorption Chiller Performance
}

\author{
N. Nasruddin ${ }^{1}$, Andre Kurniawan ${ }^{1}$, Asep Rahmat ${ }^{1}$ \\ ${ }^{1}$ Department of Mechanical Engineering \\ Universitas Indonesia \\ Kampus Baru UI Depok - West Java, 16424 Indonesia \\ Phone/Fax number: +6281585935355, e-mail: nasruddin@eng.ui.ac.id
}

\begin{abstract}
The purpose of this study was to study the performance of silica gel-air adsorption chiller on two types of adsorber fins by conducting experiments at several cycle times, namely 500, 600, 700 and 800 seconds with specific mass recovery times, heat recovery times, and also variations on the input of the cooling fluid, so that optimal cycle times can be obtained related to $\mathrm{COP}$ and SCP. The adsorber fin-spacing which has more tightly fin distance does not determine the better performance of the adsorber for chiller application because the shorter distance of the fin, the cross-sectional area of the silica gel surface that has initial contact with the adsorbate will decrease so that the performance of the adsorber will decrease. The highest cooling capacity and COP obtained are $3.1 \mathrm{~kW}$ and 0.52 , respectively. The results are obtained on adsorber with 3 $\mathrm{mm}$ fin distance and $700 \mathrm{~s}$ cycle with hot water inlet temperature of $79^{\circ} \mathrm{C}$, cooling water inlet temperature of $29.4^{\circ} \mathrm{C}$ and chilled water outlet temperatures of $8.5^{\circ} \mathrm{C}$
\end{abstract}

Keywords. Adsorber, Chiller, Fin distance, Cooling capacity, Heat recovery time.

\section{Introduction}

Electricity consumption for cooling and air conditioning systems is estimated to reach $15 \%$ of all world electricity [1,2]. Currently, most of the refrigeration and air conditioning technology commonly used is a vapor compression system that uses electrical energy and synthetic refrigerants $[3,4]$. The problem with vapor compression systems is the system consumes large amounts of electricity. In addition, the synthetic refrigerants used in compression systems have negative impacts on the environment, such as depleting the ozone layer and global warming.

One promising and potential option to replace the conventional refrigeration system (vapor compression system) to solve the energy resources and environmental problems is an adsorption cooling system. The adsorption cooling system is an environment-friendly system because utilizing natural refrigerants (such as water, methanol, ammonia and others) which could not cause the ozone layer depletion and global warming. This system can also utilize industrial waste heat, geothermal heat and solar thermal energy as energy sources. The results of the previous study indicated that the adsorption system can utilize solar energy for cooling application $[2,5,6]$. With the high and stable potential of solar radiation in Indonesia, which is $4.8 \mathrm{kWh} / \mathrm{m} 2$ / day throughout the year [3], then this adsorption system is feasible to be developed and operated using solar energy in Indonesia.

Adsorber is one of the main parts of the adsorption chiller. Adsorption system performance is influenced by adsorber design. Many types of adsorber are designed and used for adsorption chiller. One of the adsorber is fin-tube type. There are many design parameters of fintube adsorber which can be variated e.g. fin thickness, tube length and diameter, materials of the fin or tube and also fin spacing.

Nasruddin et al. [7] modelled and simulated a two-bed silica gel-water adsorption chiller with heat and mass recovery processes, utilizing solar energy based in the tropical climate of Indonesia. It is shown that during the maximum and minimum value of irradiation, the average value of COP can reach 0.26 and 0.15 . Meanwhile, the cooling capacity is maximum value of $37.8 \mathrm{~kW}$ and at the minimum of $5.3 \mathrm{~kW}$.

Djubaedah et al. [8] simulated and optimized a two-bed solar adsorption chiller with two different working-pair candidates, namely silica gel-water and zeolite-water. Optimization using a multi-objective genetic algorithm was performed to find out the optimum condition of the system for two objective functions e.g. thermodynamic and economic point of view. Destruction of exergy and total annual costs are two objective functions that are examined while the solar collection area, the mass flow rate of the cooling water, the mass flow rate of the hot water, and the mass flow rate of the cold water are chosen as decision variables to optimize the system. It is shown that the zeolite-water pair had a lower value of exergy destruction and annual costs compared to the 
silica gel-water pair, which produced 150,938 Watts of exergy destruction at an annual cost of \$216,818 USD. However, zeolite-water pair have a lower cooling capacity and coefficient of performance (COP) than silica gelwater.

Pan et al. designed a silica gel-water adsorption chiller using mass recovery process and applied for the chiller with extra low temperature waste heat utilization under conditions of lower than $80^{\circ} \mathrm{C}$ as driving hot water temperature and using silica gel-water adsorption cooling. It is shown that the silica gel-water adsorption chiller has a good performance at extra low temperature waste heat utilization [9].

The purpose of this study is to study the performance of silica gel-air adsorption chiller on two different types of adsorber fins by conducting experiments at several cycle times, e.g. 500, 600, 700 and 800 seconds with specific mass recovery times, heat recovery times, and also some variations on the input of the cooling fluid, so that optimal cycle times can be obtained related to COP and SCP.

\section{Adsorption Chiller}

The adsorption chiller components are two-bed adsorbers, condenser, evaporator and piping systems of hot water systems, cooling water systems and chilled water systems. The system is equipped with ten valves. The schematic diagram of the valve system and piping of adsorption chiller can be seen in Figure 1. The adsorbent and adsorbate pair used in this experiment is silica-gel and water.

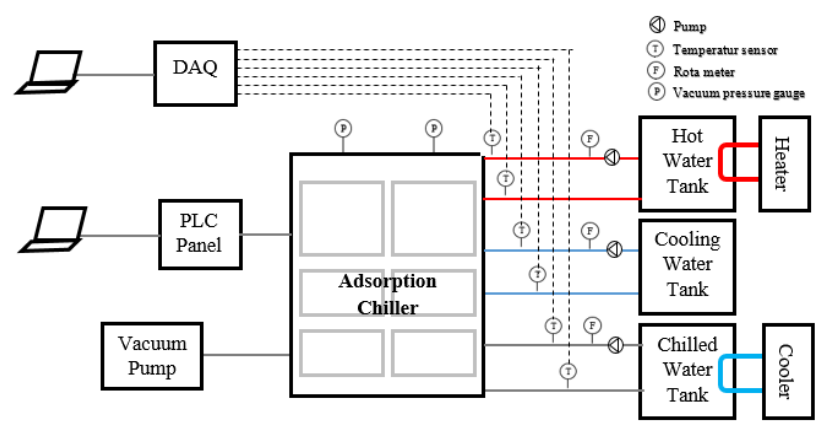

Fig. 1. Schematic diagram of adsorption chiller

In this experiment four different modul of adsorber which consists modular rectangular finned-tube with horizontal arrangement as shown in Figure 2. Each moduls consists of 0.5 inch diameter copper tube pipe, alumunium fins, and silica gel powder inserted between the fins. Two different types of fin spacing e.g. $2 \mathrm{~mm}$ and $3 \mathrm{~mm}$ are applied for this experiment.

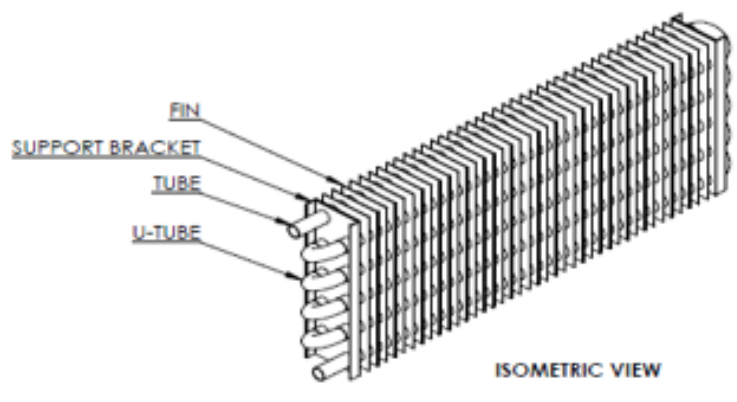

Fig. 2. Rectangular Finned-tube

In this experiment the effect of cycle time of the adsorption cycle with 2 different fin spacing are examined. Since the adsorption is a transient process, it is interesting to analyze from outlet temperature profile at a constant inlet temperature of the adsorption chiller system. The relation of cooling power variations related to COP (Coefficient of Performance) and SCP (Specific Cooling Capacity) for different cycle times will show the characteristics of system performance.

Since the total adsorption capacity depends on the total mass of the adsorbent, it is very important to know the specific value as a benchmarking parameter between one adsorption chiller to another based on the adsorbent mass charging into the adsorber.

The performance characteristics of an adsorption system are calculated by the chiller cooling capacity production, the heat input into the system, COP and SCP which are calculated with the following equations:

$$
\begin{gathered}
Q_{e}=m_{c h} C_{p, w}\left(T_{c h, i n}-T_{c h, o}\right) \\
Q_{h}=\dot{m}_{h} C_{p, w}\left(T_{h, i n}-T_{h, o}\right) \\
\operatorname{COP}=\frac{Q_{g}}{Q_{h}} \\
S C P=\frac{Q_{e}}{m_{s}}
\end{gathered}
$$

\section{Result and Discussion}

The typical temperature profiles of the adsorption chiller system are shown in Figure 3. The hot water inlet temperature is $79^{\circ} \mathrm{C}$ as an input water for desorption process. Since desorption process is a transient process, the outlet hot water temperature can vary as function of time. The similar effect is also taken place for adsorption process, the inlet cooling water constant temperature of $30^{\circ} \mathrm{C}$ flows into the adsorber chamber. The chilled water produced in this cycle is around $8.5^{\circ} \mathrm{C}$.

The effect of the cycle time on the adsorption chiller performance for $2 \mathrm{~mm}$ and $3 \mathrm{~mm}$ fin-spacing are shown in Figure 4. In general, the performance of the adsorber with $3 \mathrm{~mm}$ fin-spacing is better than $2 \mathrm{~mm}$ fin-spacing. It can be explained that with $3 \mathrm{~mm}$ fin-spacing the total mass of the adsorbent e.g. silica gel is more than the 
other. Adsorption capacity will increase with increasing the mass of the adsorbent. Experimental results show that the performance effect of increasing the area of the fin adsorber is minor as compared with total mass of adsorbent. The mass transfer effect is more dominating the performance system than heat transfer effect.

Figure 4 and 5 show that cooling power related to SCP. During the $500 \mathrm{~s}$ cooling cycle, the adsorption chiller has the highest SCP value. By increasing the cooling cycle time, the highest COP value is obtained at the cycle time of $700 \mathrm{~s}$.

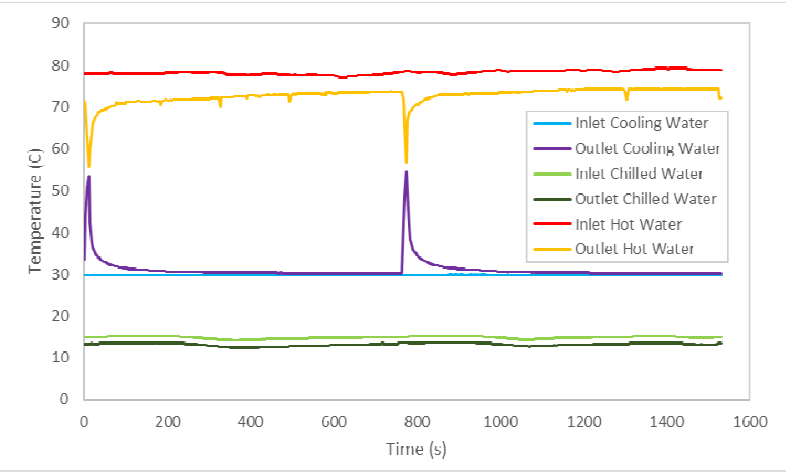

Fig.3. Temperature profiles of adsorption chiller

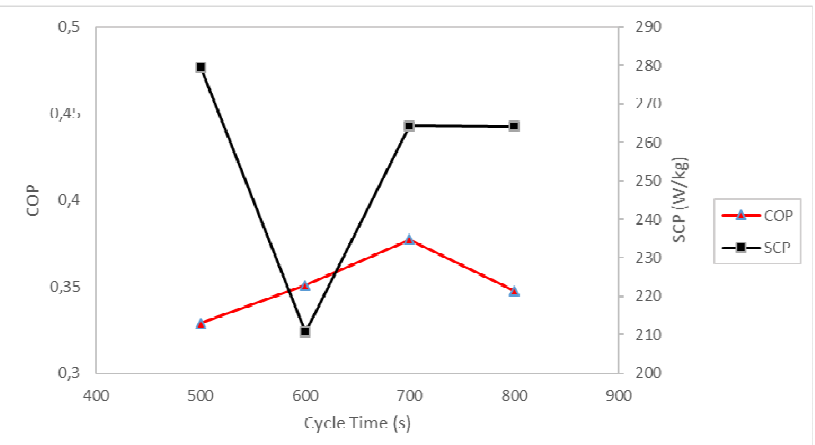

Fig.4 COP and SCP as Function of Cycle Time for $3 \mathrm{~mm}$ Fin Distance

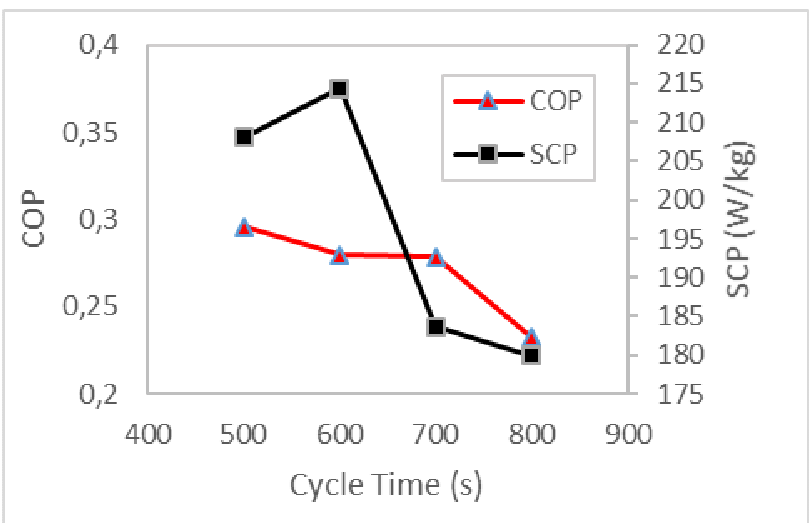

Fig.5 COP and SCP as Function of Cycle Time for $2 \mathrm{~mm}$ Fin Distance

\section{Conclusion}

The adsorber fin-spacing which has more tightly fin distance does not determine the better performance of the adsorber for chiller application. because the tighter distance of the fin, the cross-sectional area of the silica gel surface that has initial contact with the adsorbate will decrease so that the performance of the adsorber will decrease. The highest cooling capacity and COP obtained are $3.1 \mathrm{~kW}$ and 0.52 , respectively. The better results are obtained on adsorber with $3 \mathrm{~mm}$ fin spacing and $700 \mathrm{~s}$ cycle with hot water inlet temperature of $79^{\circ} \mathrm{C}$, cooling water inlet temperature of $29.4^{\circ} \mathrm{C}$ and chilled water outlet temperatures of $8.5^{\circ} \mathrm{C}$.

\section{Acknowledgement}

The authors would like to thank to DRPM Universitas Indonesia for supporting this research through Hibah PITTA 2019.

\section{Nomenclature}

$\begin{array}{ll}\mathrm{Q}_{\mathrm{h}} & \text { Heat from Hot water }(\mathrm{kW}) \\ \mathrm{Q}_{\mathrm{e}} & \text { Cooling capacity }(\mathrm{kW}) \\ \mathrm{SCP} & \text { Spesific cooling performance }(\mathrm{W} / \mathrm{kg}) \\ \Delta H & \text { Adsorption isosteric heat }(\mathrm{J} / \mathrm{kg}) \\ \dot{m} & \text { mass flow rate }(\mathrm{kg} / \mathrm{s})\end{array}$

\section{References}

[1]. Goyal, P., et al., "Adsorption refrigeration technology-An overview of theory and its solar energy applications", Renewable and Sustainable Energy Reviews (2016). Vol. 53, pp. 1389-1410.

[2]. Fernandes, M., et al., "Review and future trends of solar adsorption refrigeration systems", Renewable and Sustainable Energy Reviews (2014). Vol. 39, pp. 102-123.

[3]. Kavanaugh, S.P., "HVAC Simplified", ASHRAE, Atlanta (2005)

[4]. Hasan, M., T. Mahlia, and H. Nur, "A review on energy scenario and sustainable energy in Indonesia", Renewable and Sustainable Energy Reviews (2012) Vol 16(4), pp. 2316-2328.

[5]. Wang, R., L. Wang, and J. Wu, "Adsorption refrigeration technology: theory and application", John Wiley \& Sons (2014)

[6]. Fan, Y., L. Luo, and B. Souyri, "Review of solar sorption refrigeration technologies: development and applications", Renewable and Sustainable Energy Reviews (2007). Vol. 11(8). pp. 1758-1775.

[7]. Nasruddin, N., Lemington, L., Alhamid, M.I., "Numerical simulation of a two-bed solar-driven adsorption chiller in a tropical climate", International Journal of Technology (2015), Vol. 6 (4), pp. 594-603

[8] Djubaedah, E., Rachmat, A., Aisyah, Nasruddin, Kurniawan, A., "Multi-objective optimization of a two-bed solar adsorption chiller based on exergy and economics", International Journal of Technology (2018), Vol. 9 (6), pp. 1276-1284

[9] Pan, Q., Peng, J., Wang, R., "Experimental study of an adsorption chiller for extra low temperature waste heat utilization", Applied Thermal Engineering (2019), Vol. 163, pp. 1-8. 